\title{
Women's Involvement in Income Generating Activities and Their Opinion About Its Contribution: A Study of Gazipur District, Bangladesh
}

\author{
Shaikh Shamim Hasan ${ }^{1,2, *}$, Moushumi Hossain², Sabina Sultana ${ }^{3}$, Mithun Kumar Ghosh ${ }^{4}$ \\ ${ }^{1}$ Institute of Geographic Sciences and Natural Resources Research (IGSNRR), Chinese Academy of Sciences (CAS), Beijing, China \\ ${ }^{2}$ Department of Agricultural Extension and Rural Development (AER), Bangabandhu Sheikh MujiburRahman Agricultural University \\ (BSMRAU), Gazipur, Bangladesh \\ ${ }^{3}$ Department of Agricultural Extension, Gazipur SadarUpazila, Gazipur, Bangladesh \\ ${ }^{4}$ Department of Agricultural Extension and Rural Development, EXIM Bank Agricultural University, Chapainawabganj, Bangladesh
}

\section{Email address:}

shinuextn120@yahoo.com (S. S. Hasan), shamim@igsnrr.ac.cn (S. S. Hasan), shamim.aer@bsmrau.edu.bd (S. S. Hasan)

\section{To cite this article:}

Shaikh Shamim Hasan, Moushumi Hossain, Sabina Sultana, Mithun Kumar Ghosh. Women's Involvement in Income Generating Activities and Their Opinion About Its Contribution: A Study of Gazipur District, Bangladesh. Science Innovation. Vol. 3, No. 6, 2015 , pp. 72-80. doi: $10.11648 /$ j.si.20150306.13

\begin{abstract}
The study was conducted to determine the socioeconomic characteristics ofthe respondents participating in different agricultural income generating activities, to attain the nature and extent of participation in different Income Generating Activities (IGAs) and find out the relationship between the selected characteristics of the respondents and their opinion in poverty alleviation through IGAs. An interview schedule was used to collect needed information through face to face interview from randomly selected sample size of 125 respondents. The respondents showed remarkable individual differences in their characteristics and majority $(84 \%)$ of them belonged to young and middle aged category having high literacy rate (86.7\%). Most of the respondents' family size was small and medium (90.6\%) and having small (96\%) farm size. Most of the respondents' (78.7\%) annual income was up to Tk 200000 and they have medium (60\%) agricultural knowledge, favourable attitude (78.7\%) towards participation in IGAs. Most of the respondents had higher participation (48.1\%) in IGAs. The income from IGAs was high $(86.7 \%)$ and opinion regarding poverty alleviation through IGAs should substantial improvement (65.3\%). Education, family size, agricultural knowledge, respondent's attitude, participation in IGAs, income from IGAs were found to have significant relationship with the respondents' opinion on poverty alleviation through IGAS. High price of inputs, frequent absence of members in time, lack of marketing facilities and social sanction for the women for going activities outside homestead were the major problems faced by the respondents.
\end{abstract}

Keywords: Income Generating Activities (IGAs), Opinion, Women Involvement, Contribution

\section{Introduction}

Bangladesh is one of the least developing countries of the world with women comprises about half of the total population of the same (Sultana et al., 2010). Bangladesh is a least developing country with rural population is about 114.7 million (Anonymous, 2013) of which more than $80 \%$ people live in rural areas (Sultana et al., 2010). This population comprises about 57.9 million women (Anonymous, 2013) who live in rural areas of the country. Women constitute almost half of the total population of the country (Sultana et al. 2010). Urbanization is observed as a rapid process in most of the developing as well as transition countries of the world, although poverty is still remains with the rural area and rural people (IFAD, 2001) as majority of the poor live basically in rural areas and also these trends are expected to continue in near future (Carletto et al. 2007).Although women constitute half of the total population of the country, women in Bangladesh experienced from multiple destitutions (Sultana and Hasan, 2010). It is a matter of heartbreak that they are dependent economically, educationally behind, also socially and politically disadvantaged and backward position (Sarker and Rahman, 2007).Discrepancies exist between men and women in Bangladesh with in most of sectors like health, education, employment income sector, controlling on the assets, self security and also taking part in different political 
processes of the country although they are playing a crucial role in and outside of their home (Hoque and Itohara, 2008).

There have been conducted several general studies of contribution of micro-credit on the economic uplift of women and their utilizations. For example, rural women in Bangladesh employed themselves in different income generating activities (IGAs) for earning money (Ahmed et al. 2011) by means of small loans as microcredit from different loan providers and improves their economic condition (Sultana and Hasan, 2010). With their increased income the women in Bangladesh operate lots of households based productive activities and small business to boost up their income. Increased income of the rural women help them, according to the findings of Sultana and Hasan (2010), to improve their cash savings, asset ownership of both productive (cattle, goat, poultry) as well as non productive (jewellery, TV/radio, small vehicle). On the other hand Downs (2007) has concluded that rural women increased income help to meet up their treatment expense, upgraded sanitation, payment of their children's school fees with improved nutrition for other members of their family. According to the study of Siddique et al. (2009) is has been shown that small loan in the form of micro-credit for the women in Bangladesh is a creator of income earning opportunity by which women can get an opportunity to engage them in various income generating activities and earn more money.In a similar attempt, Mondal et al. (2009) has confirmed that, from their study, income is the most important element of human well fare and improved living condition. It also helps to improve people's improved health, socio-economic as well as political capability. Findings form Downs (2007) have revealed that women can utilize their increased income for their medical treatment purposes, payment of children's educational institutions fees, improve the sanitation facilities, and also help to improve the diet as well as good nutritional status of the family. As the total household income of the families is improved by the help of micro-credit program and women income generating activities, so the women can also contribute for improving the housing facilities and consumption pattern that is the overall livelihood status (Hoque and Itohara, 2009; Haque and Yamao, 2009; Mondal et al. 2009; Panda, 2009). A study on "the impact of Grameen Bank micro-credit on change in livelihood status of women beneficiaries" has been conducted by Kuhinur and Rokonuzzaman (2009). They have claimed that smaller amounts of capital can flourishing the women to operate smaller business which help them to earn more to give more inputs into their family food habits, housing condition, health and also sanitary facilities.

Mazumder and Wencong (2013) work on micro-credit and poverty reduction by women in Bangladesh. They observe that by the help of micro-credit the women's income, asset endowment, standard of living is improved which ultimately reduce their poverty level. Findings from Ahmed et al. (2011) reflect that although Bangladeshi rural women having lower socio-economic status but micro-credit programs allots loans to them. By means of this credit poor women manage smaller financial activities which help them to generate income and contribute to their family wellbeing. Although a considerable volume of research has been conducted on rural women and their contribution on IGAs with the assistance of micro-credit so far, little attention has been paid on women's opinion about IGAs' contribution towards poverty alleviation. Yakoob et al. (2014) work in Pakistan on economic role of women. The respondents were involved in different types of livestock related activities as IGA. Their findings reveal that their income has a significant impact on their socio-economic status. By their research in Bangladesh on IGAs of rural women and it's relation with women's reproductive health, Islam and Mainuddin (2015) concluded that income help improving the empowerment of rural women which ultimately related with reduction of their fertility rate and changing life. In addition, Baba et al. (2009) provide that IGAs bring out off season extra income and employment for the women in Jammu and Kashmir of India.

Nevertheless, further study studies clearly need to be undertaken.

Whilst the results of Sultana and Hasan's (2010) study have claimed that majority of the women play a vital role in the different areas like different management works of crop production, livestock management and production, help in fisheries management, biological diversity, also provides energy and family management. Different types of income generating activities are found in the rural areas although agricultural related activities are the largest among all income of rural people, although a good share is also exists in terms of rural non-farm activities.It has been observed by Micevska and Rahut (2008) that in rural areas poor people employed in different nonfarm works and earn money which is treated as complement of their farm activities and marked as alternate for their farm income. They also argue that sometimes nonfarm activities are considered as a coping mechanism to insufficient land of the poor people or less income from agriculture.

Findings from different researchers (eg., Davis 2004; FAO, 1998; Reardon et al.2001) reveal that rural non-farm activities is growing more in developing and transition countries of the world accounts to $32 \%$ in Asia, $42 \%$ of rural income in Africa, $40 \%$ in Latin America and 44\% in Eastern Europe and the CIS.

Therefore women involve in different activities related to income generation which contribute more in their family income. So to mark different sectors of women's participation as well as pinpoint their views regarding IGAs contribution towards income is a focusing issue of this research.

The existing study presents the current socio-economic status of rural women in some selected areas as well their involvement in different IGAs in Bangladesh. Particular attention is paid to investigate the opinion of the respondent women about the contribution of IGAs in the way of poverty alleviation. The current research is useful to produce the end product of (1) current status of the socio-demographic attributes of the respondents; (2) degree of their participation 
in various IGAs; and (3) scrutinize the opinion of the respondents approaching the contribution of IGAs in the direction of poverty alleviation furthermore interrogating the influence of their characteristics upon their opinion.

\section{Methodology}

Deriving accurate information is highly dependent upon the survey method (Ahmed et al., 2011). According to Ogunlade and Adebayo (2009), the most commonly used approach is the direct face-to-face interview. This study is also a survey research with face to face interview is administered using interview schedule that is used to collect data from the respondents on socio-economic characteristics as well as income generating activities. Two unions (Kaultia and Mirzapur) of Gazipur Sadar Upazila (lower administrative unit) of Gazipur District of Bangladesh are selected as the study area. Women of Vaoraid village (365) of Kaultia union and Panishail (328) village of Mirzapur union are the population of the study whose total number was 693 . As sample, 70 respondents were taken from Painshail and 55 were taken from Vaoraid so that the total numbers of the respondents are 125 using simple random sampling technique. One of the causes of using simple random sampling in this study is that the number of population is smaller (only 365) and simple random sampling technique is best suited for smaller population (Moore et al. 2014). Also any member of the population (here 365) had an equal chance to being included in this study with less chance of being biasness. The entire process of data collection was conducted from October to December, 2013.

Necessary coding of data was done after collecting the data and transferred these into computer for analysis. Different analysis like frequency count, means, ranges with percentages were administered utilizing Statistical Package for Social Science (SPSS) software. To show the contribution of socio demographic characteristics of the respondents on their opinion towards poverty alleviation through IGAs, this study treated multiple regression analysis.

\subsection{Measurement of Dependent Variable}

Respondents' opinion of poverty alleviation through IGAs is the dependent variable of this study. Their opinionis measured by constructing a 3-point Likert type scale ranged from $1=$ do not and $3=$ very much. Each respondent provided their opinion by checking against six statements. The respondent's opinion score ranged from 9-18. Based on the calculation the respondents were classified into 3 categories, 1) low improvement, 2) much improvement, 3) very much improvement.

\subsection{Measurement of Independent Variable}

The independent variables of this study which influenced the respondents' opinion are age, educational attainment, family size, annual income, and annual income from different IGAs, agricultural knowledge, and respondents' attitude towards IGAs. Age of a respondent is measured in terms of actual years on the basis of his statement. Educational attainment is measured by the number of years of schooling. But if the respondent never went to school was given no marks (0). Family size referred to the total number of members of a family including the respondent herself, spouse, child and other permanent dependent who lived together as family unit. Annual income of the respondents was measured in Bangladeshi taka (BDT) on the basis of total yearly earning from agricultural and non-agricultural sources of her family. Later it is converted into US Dollars (USD). Agricultural knowledge of a respondent is computed on the basis of his responses to 15 questions present in the interview schedule covered by different aspects of agriculture. Points assign for correct answer is 2, for partially correct answer it is 1 and for incorrect answer obtains 0 . There are 10 items are accommodated in the interview schedule to judge the attitude of the respondents towards IGAs. A five point Likert type scale is deployed here for measuring attitude ranged from $1=$ strongly disagree and $5=$ strongly disagree. The range of score for the general attitude in this scale was 10 and the lowest 50 and higher values label positive attitude towards IGAs.

\section{Results and Discussion}

Table 1 showed that $76 \%$ of the respondents were in between 20 to 40 years. With an average agewas 35.46 years, The people who are in between 15 years to 29 years of age are considered as young in Bangladesh (DYD, 2007). In this study area, about $41 \%$ women were considered to be as young. An important finding from GED (2009) indicates that, rural women participation rate in labor force increases with the increase of age from 20 years and the highest participation is accounted for the age group of 40 to 44 years. During this study, it is observed that about $96 \%$ of the respondents are in between the age group of 20 to 50 years.

Literacy percentage of the respondents was enough good in the study area. About $85 \%$ of the respondents had an educational attainment of primary level to secondary or Secondary School Certificate (SSC) level. This is a good sign of women education level improvement of the country (Bangladesh). For improving the female education in Bangladesh, the Government for the last few years has been take few important actions like free distribution of the books, establishment of new schools both in urban and rural areas, full free studentship, stipend for the female students, education fee waiver, food for education etc. programs (MoEd, 2015). All these initiatives have greatly upgraded the present scenario of improvement of female education and the present findings also similar to that. Most percentage of the respondents of the study area has family size in between 02 to $06(90.40 \%)$. For administering a household family works as the oldest social unit (Anonymous, 2008). Average family members of the study area were 4.93 . The national average family size in rural areas in Bangladesh is 4.89 (Anonymous, 2015). Therefore the average family size of this study was a 
few more than that of the national average.

Data contained in Table 1 shows that the respondents has an average annual family income of 113833 BDT (1423 USD) although about $90 \%$ of the respondent's annual family income has up to 200000 BDT (2500 USD).

Respondents annual income from different IGAs range from 8500-79467BDT (106-1000 USD) with an average of 34789 BDT (435 USD). About $82 \%$ of the respondents earned up to 50000 BDT (625 USD) annually from different IGAs. According to the findings of Ahmed et al. (2011), income is a crucial aspect of judging the living standard of any human being. So involvement of the women members of the family into the income earning is common and this earning is utilized for the betterment and continuity of the family. This is a common picture for the poor families. Economic entitlement of women encompasses them to participate in decision making more into their household and also in family planning, nutrition and health condition, children survival rate with their education more specifically girl's education (Chowdhury, 2007; Parvin et al. 2005 and Steele et al. 2001).

Table 1. Demographic characteristics profile of the respondents.

\begin{tabular}{|c|c|c|}
\hline Categories & Frequencies & Percentage \\
\hline \multicolumn{3}{|l|}{ Age $($ Mean $=35.46, \mathrm{SD}=9.51)$} \\
\hline Age between 20 to 30 years & 52 & 41.60 \\
\hline Age between 31 to 40 years & 43 & 34.40 \\
\hline Age between 41 to 50 years & 25 & 20.00 \\
\hline Age between 51 to 60 years & 05 & 04.00 \\
\hline \multicolumn{3}{|l|}{ Educational attainment $(\mathrm{Mean}=6.77, \mathrm{SD}=3.37)$} \\
\hline No Education/Illiterate & 18 & 14.40 \\
\hline Primary Education & 30 & 24.00 \\
\hline Secondary (SSC level) & 74 & 59.20 \\
\hline Upper SSC level (Upto HSC level) & 03 & 02.40 \\
\hline \multicolumn{3}{|l|}{ Family size $($ Mean $=4.93, \mathrm{SD}=1.51)$} \\
\hline No. 02 to 04 & 62 & 49.60 \\
\hline No. 05 to 06 & 51 & 40.80 \\
\hline No. more than 06 & 12 & 09.60 \\
\hline \multicolumn{3}{|c|}{ Annual Income of the Family $\{$ Mean $=113833(1423$ USD) BDT, SD $=73038$ (913 USD) BDT $\}$} \\
\hline Up to 100000 BDT (1250 USD) & 61 & 48.80 \\
\hline 100001-200000 BDT (1250.01-2500 USD) & 51 & 40.80 \\
\hline Over 200001 BDT (2500.01 USD) & 13 & 10.40 \\
\hline \multicolumn{3}{|c|}{ Annual Income from different IGA $\{$ Mean $=34789 \mathrm{BDT}(435 \mathrm{USD}), \mathrm{SD}=17482 \mathrm{BDT}(219 \mathrm{USD})\}$} \\
\hline Up to $25000 \mathrm{BDT}$ & 45 & 36.00 \\
\hline $25001-50000 \mathrm{BDT}$ & 57 & 45.60 \\
\hline $50001-75000$ BDT & 20 & 16.00 \\
\hline Over 75001 & 03 & 02.40 \\
\hline \multicolumn{3}{|c|}{ Agricultural Knowledge $($ Mean $=19.32, \mathrm{SD}=3.67)$} \\
\hline $90 \%$ or more correct answer & 0 & 0 \\
\hline $81-90 \%$ correct answer & 20 & 16.00 \\
\hline $71-80 \%$ correct answer & 24 & 19.20 \\
\hline $61-70 \%$ correct answer & 54 & 42.20 \\
\hline $51-60 \%$ correct answer & 27 & 21.60 \\
\hline $50 \%$ or less correct answer & 0 & 0 \\
\hline \multicolumn{3}{|c|}{ Attitude towards IGAs $($ Mean $=34.38, \mathrm{SD}=7.28)$} \\
\hline Less favourable attitude (score $\leq 34$ ) & 54 & 43.20 \\
\hline Favourable attitude (score between 35 - 41) & 49 & 39.20 \\
\hline Highly favorable attitude (score $>42$ ) & 22 & 17.60 \\
\hline
\end{tabular}

Note: 1 USD $=80$ Bangladeshi Taka (BDT)

Cent percent of the respondents give $50 \%$ to $90 \%$ correct answers to questions related to agriculture. No respondents answers more than $90 \%$ and less than $50 \%$ correct answers. About $57 \%$ respondents has favourable to highly favourable attitude towards IGAs. Findings of Salawat et al. 2013 in their work on "Study on knowledge and attitude of Mushroom growers at selected upazilas of Dhaka District" also indicated that about $71 \%$ women mushroom growers of the study area had moderately favourable attitude towards mushroom cultivation and which ultimately helped them to earn more income from this enterprise.

\subsection{Different IGAs Practiced by the Respondents in the Study Area}

Rural women are contributing important role in almost all the aspects of the society and their contribution towards the accessibility of natural, social, financial and human capital 
for sustainable livelihood is meaningful (UNIFEM, 1998). Rural women also participating in all the steps of agricultural production spanning from seed sowing to harvesting. Not only that, their participation is also scrutinized in both on farming and non-farming activities directly and also incidentally, in fact, they utilizes extensively small farmlands and homestead areas for production and income (ADB, 2004). However, Sheheli (2012) identified also two broad categories of IGAs, ie., agricultural and non agricultural activities. In this study, the respondents also performed both agricultural and non agricultural activities as IGAs and mostly performed seasonal vegetable cultivation, tree plantation, poultry production, goat raising, cattle raising, fish culture, rice processing and other cottage industries etc.

Table 2. Respondentsparticipation of different IGAs.

\begin{tabular}{|c|c|c|}
\hline Name of the IGAs & No. & Percentage \\
\hline $\begin{array}{l}\text { Seasonal vegetable cultivation } \\
\text { Tree plantation }\end{array}$ & 75 & 100 \\
\hline Nursery of fruit seedlings and selling & 75 & 100 \\
\hline Nursery of timber seedlings and selling & 65 & 86.6 \\
\hline Poultry production & & \\
\hline Layering & 65 & 86.6 \\
\hline Broiler production & 35 & 46.6 \\
\hline $\begin{array}{l}\text { Goat raising } \\
\text { Cattle raising }\end{array}$ & 69 & 92 \\
\hline Milking cow rearing & 71 & 94.6 \\
\hline $\begin{array}{l}\text { Beef fattening } \\
\text { Fish culture }\end{array}$ & 35 & 46.6 \\
\hline Mini pond culture & 67 & 89.3 \\
\hline Rice cum fish culture & 28 & 37.3 \\
\hline Cottage industry & & \\
\hline Making bag & 22 & 29.33 \\
\hline Making handicraft & 61 & 81.3 \\
\hline Making wall mat & 20 & 26.6 \\
\hline Making flower sue & 18 & 24 \\
\hline Rice processing & & \\
\hline Rice husking and selling & 73 & 97.3 \\
\hline Puffed rice (Muri) making and selling & 53 & 70.6 \\
\hline Small business related to agriculture & 72 & 96 \\
\hline
\end{tabular}

According to the data presented in Table 2, cent percent of the respondent cultivated vegetables seasonally and also planted tree as nursery for tree seedling and selling utilizing their fallow lands and back side of homestead areas. Mustafa et al. (2000) also argue that the pond side, the back yard and also cow shed of the homestead areas are utilized for planting trees. These are proved as very important IGAs of the respondents. A finding from Khan et al. 2009 indicates that homestead gardening is the leading agricultural activity of the Bangladeshi rural women and that occupies the lion's share of the poor farmers livelihood resources (Ali et al. 2008).

Poultry production is another important IGA of the study area and about $86 \%$ of the respondents raised poultry for layering also some broiler production. Because, poultry production requires smallerspace for accommodation. Not only is that livestock rearing another important enterprise of the women includes both cow (about 94\%) and goat (92\%) raising in the study area. Poor and landless households in
Bangladesh utilize the livestock sector as a mean of their survival with an important associate sector for unemployed (Shamsuddoha, 2009) which are also associated with the collection and selling of dried dung cake by the poorest women during cooler time of the year. Islam (2008) also identifies an important approach prevailing in Bangladesh is that poor women are taking animals as share basis. The poor women take animal and rear animal from the rich people as a $50 \%$ return share basis with offspring. Several studies quoted from Jahan and Rahman (2003); Parveen (2008) supported that in Bangladesh taking care of livestock is mainly done by women. Livestock take care includes graze, feeding preparation, feeding and cleaning of the animals and also their shed, sometimes milking the cows etc. Rahman (2003) also identifies poultry production as an important activity of income generation which is carried out by the women in Bangladesh. This finding is supported by BRAC (2007) and they concluded that $94 \%$ of the poultry production is owned by the women in Bangladesh which is the pivotal contributor of the household nutrition, income and savings ultimately food security (Nielsen etal. 2003; Sonaiya, 2007; Smucker and Wisner, 2008). Moreover, for up gradation of income level of the poor, poultry production is a quick and good return investment strategy (Islam et al. 2010).

In this study form the findings it is clear that about $89 \%$ and $37 \%$ women are involved with mini pond culture and rice cum fish culture respectively as IGA. Findings from Rahman and Naoroze (2007) also indicate that pond fish production is an important employment creator for the women which ultimately help to improve their standard of living. They also concluded that women can manage and produce fishes in smaller pond which are associated with their homestead areas.

From the findings of Table 2, it is indicated that the women of the study area are performing several nonfarm IGAs like making bag, handicrafts, wall mat, flower sue, puffed rice making and selling. All these areas are important source of income generation for the women of the study area. In the study area about $96 \%$ of the respondents were engaged with small business related with agriculture. Nonfarm self employment activities is common by the women as an important IGA and income earning. The important activities includes dressmaking, embroidered quilt or nakshikatha, wall mats jute bags, bamboo work, basket making, household accessories etc. (Al-Amin, 2008).Fakir (2008) and Farid et al. (2009) also concludes that women in Bangladesh also conduct several small businesses like small shop keeping, trading video cassettes, operate small grocery shops close to their homes, sometimes moving from place to place for selling cloths and other household items.

\subsection{Respondents' Opinion on Poverty Alleviation Through IGAs}

Most of the respondents had favourable attitude towards it. The range of the respondents opinion was 9-18 with an average of 14.16.On the basis of the respondents opinion of poverty alleviation through IGAs they were classified into 
three categories.

About $65 \%$ respondents give their opinion that IGAs accelerate much to very much improvement of their poverty reduction. Ahmed et al. (2011) through their study conducted on the Bangladeshi women found that those women who received credit contributed much higher to their family incomes than their counterparts (without credit). They also concluded that through different IGAs performed by the women with participating micro-credit program operated by the Grameen Bank of Bangladesh, contributed more towards family income. In the long run this improved income is treated as life sustaining issue. It is clear from the study of
Zaman (2009) who conducted his study in Bangladeshi women to assess poverty and vulnerability impact of microcredit and summarized that vulnerability can be checked through more involvement in IGAs. Javed et al. (2006) through their study on Pakistani women about the impact of micro-credit scheme on socio-economic conditions of female community, pointed out that micro-credit was treated as a better option for women empowerment of the study area as it had impact on the socio-economic condition. All these research findings are aligned with the current research findings.

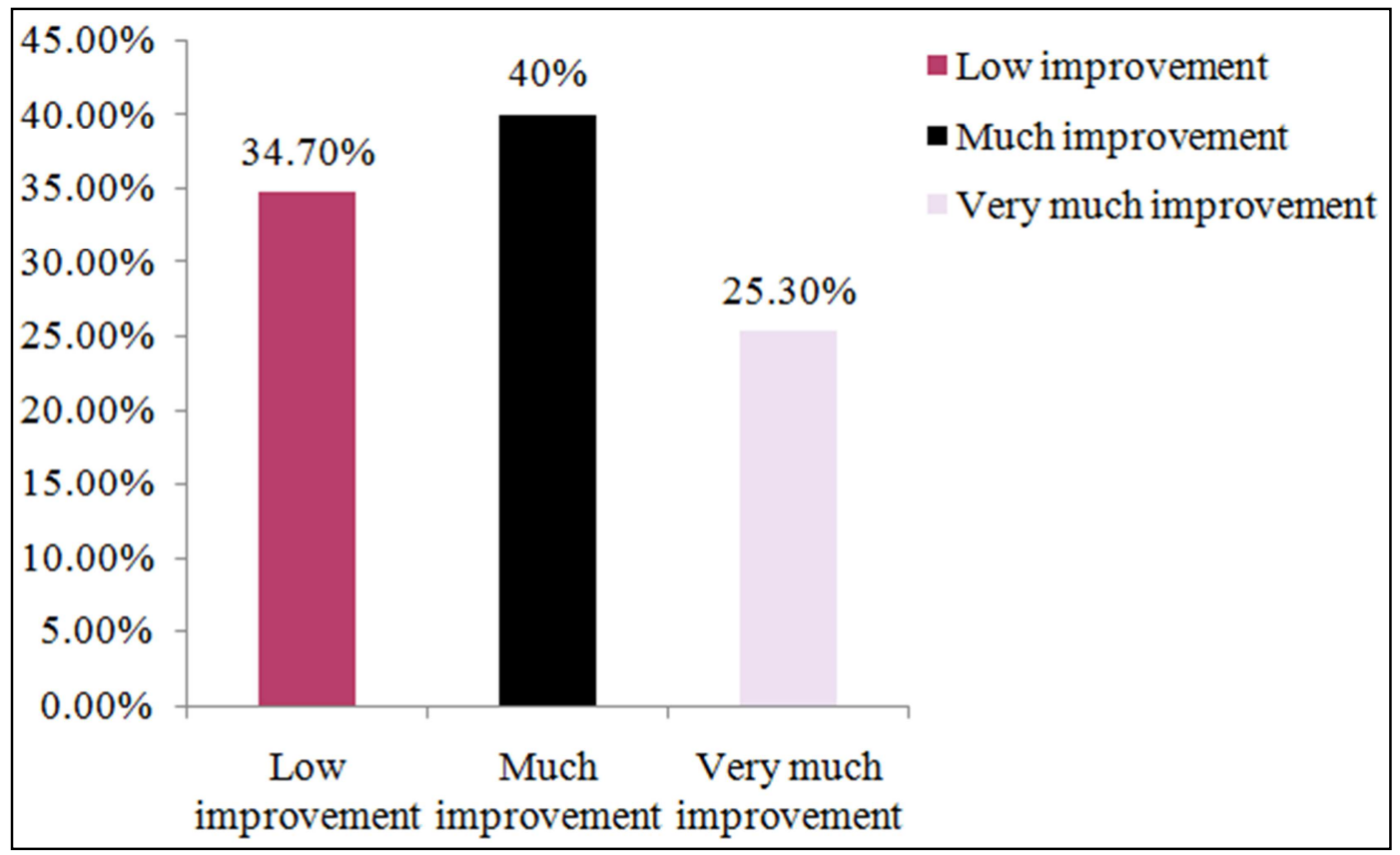

Figure 1. Distribution of the women according to their opinion towards IGAs.

\subsection{Influence of Respondents Characteristics upon Their Opinion on Poverty Alleviation Through IGAS}

This section examines the respondents several characteristics that influence their opinion on poverty alleviation by IGAs of different types. Regression results in Table 3 indicate that among seven characteristics that entered into the model, three are found to be statistically significant predictors which are 1) annual income from different IGAs; 2) agricultural knowledge and 3) attitude towards IGAs that influence on respondents opinion on poverty alleviation. These variables together explained $67.6 \%$ of the variance of effective factors on respondents opinion on poverty alleviation through IGAs. The respondents who retained one or more of these characters at a higher level were found to have a higher level of opinion of poverty alleviation; hence they can participate more with different types of IGAs and earn and contribute more to alleviation poverty in household level.

The estimated result of the multiple regression analysis is satisfactory as it fulfils some of the criteria. Firstly, the adjusted $\mathrm{R}^{2}$ (which is the measure of goodness of fit of the estimated regression model) value of 0.656 indicates a good fitting of the model. The model also depicts that $\mathrm{R}$ value is of $0.822, \mathrm{R}^{2}$ value of 0.676 and the F-test shows that the estimated regression is quite relevant which means dependent variable is related to each specified explanatory variables. Secondly, three of the estimated coefficients are statistically significant at the 0.01 level, which is significantly different from zero.

Table 3. Respondents characteristics and their influence on opinionon poverty alleviation through IGAs.

\begin{tabular}{lllll}
\hline Variables & Coefficient (B) & SE & t-value & p \\
\hline Age & 0.010 & 0.022 & 0.017 & 0.884 \\
$\begin{array}{l}\text { Educational attainment } \\
\text { Family size }\end{array}$ & -0.057 & 0.046 & -0.895 & 0.372 \\
$\begin{array}{l}\text { Annual income of the } \\
\text { family }\end{array}$ & -0.000 & 0.092 & -0.004 & 0.997 \\
$\begin{array}{l}\text { Annual income from } \\
\text { different IGAs }\end{array}$ & -0.044 & 0.000 & -0.760 & 0.449 \\
$\begin{array}{l}\text { Agricultural } \\
\text { knowledge }\end{array}$ & 0.538 & 0.000 & 6.835 & 0.000 \\
$\begin{array}{l}\text { Attitude towards IGAs } \\
\text { An }\end{array}$ & 0.376 & 0.038 & -3.360 & 0.001 \\
\hline
\end{tabular}

Note: $\mathrm{R}=0.822, \mathrm{R}^{2}=0.676$, Adjusted $\mathrm{R}^{2}=0.656$, Critical Value of $\mathrm{F}=$ 34.84 , and ${ }^{*} \mathrm{p}<0.001$ 
Ahmed et al. (2011) have illustrated that after joining in Grameen Bank's micro-credit program which is accelerated by loan and training, the women get an opportunity to increase their income through involvement of IGAs in Bangladesh. This income pushes the overall family income to forward direction which ultimately results in upgraded social status and is considered to be a good weapon of them against stumbling block of the society. Islam and Sultana (2006) further add that earning money of the women members of the family helps to upgrade their status in the feeling of their husband, family members, relatives as well as neighbours although the status of women contribution is previously disrespected.

\section{Conclusions}

To sum up, the present study gives final results that women in the study area are mostly in between 20 to 50 years of age with primary to secondary level of education. Their average family size is quite equal to the average family size of Bangladesh. Their average annual earnings from different IGAs are as equal to 435 USD which helps them to escalate their contribution towards the betterment of their family. Substantial agricultural knowledge accompanied by favourable attitude towards IGAs motivated the respondents to participate more in different IGAs and earn extra income. Although both agricultural (vegetables cultivation, tree plantation, poultry and domestic animal rearing, tree plantation, fish culture) and non-agricultural (cottage industry, rice processing and small business) IGAs are operated by the respondents. However, agricultural IGAs are predominant. Participation of the respondents into different IGAs expedites their income ultimately support them to bring much positive opinion as income from IGAs are good alleviators of poverty. Three characteristics of the respondents (annual income from IGAs, agricultural knowledge and attitude towards IGAs) have significant influence on their opinion towards IGAs. Thus good return from IGAs, good agricultural knowledge and positive attitude towards IGAs guided the respondents to take part more in different IGAs and earn more which help them supporting relieve poverty from their household. Therefore the findings of the study suggest that after joining into different IGAs the women are triggered more to earn money to help to boost up their current situation into a more positive direction. This situation can be accelerated more by arranging more need based training program and extension activities related to agriculture for upgrading their knowledge and attitude towards IGAs.

\section{References}

[1] ADB 2004. Bangladesh: Gender, Poverty and the Millennium Development Goals. ADB Country Gender Strategy, Bangladesh Resident Mission and Regional and Sustainable Development Department. Manila, Philippines: Asian Development Bank.
[2] Ahmed, F., Siwar, C. and Idris, N. A. H. 2011. Contribution of Rural Women to Family Income Through Participation in Microcredit: An Empirical Analysis. American Journal of Applied Sciences 8 (3): 238-245. Available at: http// thescipub.com/PDF/ajassp.2011.238.245.pdf.

[3] Al-Amin, S. 2008. Role of Women in Maintaining Sustainable Livelihoods of Char Landers in Selected Areas of Jamalpur District. PhD Thesis. Department of Agricultural Extension Education Bangladesh Agricultural University, Mymensingh.

[4] Ali, M. Y., Ahmed, M. M., and Islam, M. B. 2008. Homestead Vegetable Gardening: Meeting the Need of Year Round Vegetable Requirement of Farm Family. Paper presented in the National Workshop on Multiple Cropping held at Bangladesh Agricultural Research Council, Farmgate, Dhaka1215, Bangladesh on 23-24 April, 2008.

[5] Anonymous. 2008. Statistical Yearbook of Bangladesh 2007, 27th edn, Bangladesh Bureau of Statistics, Panning Division, Ministry of Planning, Government of the People's Republic of Bangladesh, Dhaka.

[6] Anonymous. 2013. Gender Statics of Bangladesh 2012. Bangladesh Bureau of Statistics, pp. 9-12. Available at: http// bbs.gov.bd/WebTestApplication/userfiles/Image/Health_Demo /Gender_Statistics.pdf.

[7] Anonymous. 2015. Average household size by sex of head of household and residence. Bangladesh Bureau of Statistics. Available at: http//bbs.gov.bd/RptHIES_2_1.aspx.

[8] Baba, Z. A.; Hakeem, A. H.; Ganai, N. A.; Malik, K. M.; Sheikh, T. A. 2009. Role of rural women in agriculture and income generating activities. Asian Journal of Home Science, 4 (1):1-3.

[9] BRAC, 2007. At a Glance. (on line accessed 10 Octobar, 2009). http://www. brac.net.

[10] Carletto, M. K., Covarrubias, B.D., Krausova, M., Stamoulis, K., Winter, P. and Zezza, A. 2007. Rural income generating activities in developing countries: re-assessing the evidence. Electronic Journal of Agricultural and Development Economics, Agricultural Development Economics Division (ESA) FAO, Vol. 4, No. 1, 2007, pp. 146-193. Available at: http//ageconsearch.umn.edu/bitstream/112596/2/ai195e00.pdf.

[11] Chowdhury, M. J. A. 2007. Does the Participation in the Microcredit Programs Increase Consumption of Participating Households? The Case of the Grameen Bank in Bangladesh. Center for Microfinance and Development (CDM) Working Paper 03, University of Dhaka, Bangladesh, 1-16.

[12] Davis, J. 2004. The Rural Non-Farm Economy, Livelihoods and their Diversification: Issues and Options Chatham, UK: Natural Resource Institute.

[13] Downs, M. 2007. Microcredit and Empowerment among Women Cloth Dyers of Bamako, Mali. Ph.D. dissertation. The graduate school of the University of Florida. Available at: http://gradworks.umi.com/32/71/3271127.html.

[14] Fakir, S. K. 2008. Women Empowerment through Participation in Income Generating Activities of Sabalamby Unnayan Samity. PhD Thesis. Department of Agricultural Extension Education Bangladesh Agricultural University, Mymensingh.

[15] FAO. 1998. The State of Food and Agriculture: Rural NonFarm Income in Developing Countries. Rome: Food and Agriculture Organization. 
[16] Farid, K. S., Mozumdar, L., Kabir, M. S., and Goswami, U. K. 2009. Nature and Extent of Rural Women's Participation in Agricultural and Non-agricultural Activities. Agricultural Science Digest, 29(4).

[17] Haque, M. S. and Yamao, M. 2009. Can microcredit alleviate rural poverty? A case study of Bangladesh. World Academy Science, Engineering and Technology, 46: 648-656.

[18] Hoque, M. and Itohara, Y. 2008. Participation and decision making role of rural women in economic activities: A comparative study for members and non-members of the micro-credit organizations in Bangladesh. Journal of Social Science, 4: 229-236. Available at: http//DOI: 10.3844/jssp.2008.229.236.

[19] IFAD .2001. Rural Poverty Report 2001: The Challenge of Ending Rural Poverty. Oxford: Oxford University Press for International Fund for Agricultural Development.

[20] Islam, S. and Mainuddin, A. 2015. Relationship between income generating activities of rural women and their reproductive health behavior in Bangladesh. Journal of Rural and Remote Health Research, Education, Practice and Policy.

[21] Islam, M. S., Takashi, S., and Chhabi, K. Q. N. 2010. Women's Contribution to Self-financed Small-Scale Independent Broiler Farming and their Participation in Farm Extension Activities in Rural Bangladesh. Livestock Research for Rural Development. Volume 22, Article \# 141.

[22] Islam, M. Z. A. 2008. Survival Strategies of the Female Displaces in Rural Bangladesh: A Study of Two Riparian Villages on the Right Bank of Jamuna. XII World Congress of Rural Sociology, Goyang, Korea. Available at http://www.irsaworld.org/XII/papers/2-1.pdf (searched date: 14 July 2011).

[23] Islam, N. and Sultana, N. 2006. The status of women in Bangladesh: Is the situation really encouraging? Research Journal of Social Science, 1: 56-65.

[24] Jahan, N. and Rahman, H. 2003. Livestock Services and the Poor in Bangladesh: A Case Study. Danish Agricultural Advisory Centre, Udkaersvej 15, Skejby, DK- 8200 Aarhus N, Denmark. An Initiative by Danida, IFAD and World Bank. Availableat

http://lr.dynamicweb.dk/Files/Filer/Global/Bangladesh_case_s tudy.pdf (searched date: 10 August 2011).

[25] Javed, A, Muhammad, L., Khan A. S., and Farah A. A. 2006. Impact of Micro Credit Scheme of NRSP on the Socio Economic Conditions of Female Community in District Rawalakot, azad Jamu and Kashmir, Pakistan. Journal of Agriculture \& Social Sciences. 2(3)142-144.

[26] Khan, M. A. H., Ali, M. Y., Quayyum, M. A., Nazrul, M. I. and Hossain, M. J. 2009. Year Round Homestead Vegetable Production: A Means of Reducing Poverty and Nutritional Deficiency For Small Farm, Bangladesh. Journal of Agricultural Research, 34(1): 169-174.

[27] Kuhinur, S. and Rokonuzzaman, M. 2009. Impact of Grameen Bank micro credit on change in livelihood status of women beneficiaries. J. Bangladesh Agril. Univ., 7: 381-386. DOI: $10.3329 /$ jbau.v7i2.4750.

[28] Mazumder, M. S. U and Wencong, L. 2013. Micro-credit and poverty reduction: A case of Bangladesh. Prague Economic Papers, 22 (3): 403-417. DOI: 10.18267/j.pep.459.

[29] Micevska, M. and Rahut, D. B. 2008. Rural Nonfarm
Employment and Incomes in the Himilayas. Working Paper No. 205. New Dehli: Indian Council for Research on International Development.

[30] Ministry of Education (MoEdu). 2015. Peoples Republic of Bangladesh. www.moedu.gov.bd.

[31] Mondal, N. I., A. R. Khan, J. Chakma and G. Hossain, 2009. Family structure, economic security and educational status of rural chakma in CHT of Bangladesh. Journal of Social Science, 19: 219-224.

[32] Moore, D. S., George, P. M., Bruce, C. and Michael, W. P. 2014. Introduction to practice of statistics. W. H. Freeman \& Co. Ltd. USA.

[33] Mustafa, M. M., Khan, N. A., Osman, H. A. K., and Shamsuzzaman, S. M. 2000. Research on Home Gardens in Bangladesh: Present Status and Properties for the New Millennium. In: Khan, N. A. (ed.), Indigenous Practices in Bangladesh BARCICK, Dhaka. 107-117.

[34] Nielsen, H., Roos, N., and Hilsted, S. H. 2003. The Impact of Semi-Scavenging Poultry Production on the Consumption of Animal Source Foods by Women and Girls in Bangladesh. The Journal of Nutrition, 133: 4027S-4030S.

[35] Ogunlade, I. and Adebayo, S. A. 2009. Socio-economic Status of Women in Rural Poultry Production in Selected Areas of Kwara State Nigeria. International Journal of Poultry Science, 8: 55-59.

[36] Panda, D. K. 2009. Participation in the Group Based Microfinance and its Impact on Rural Households: A Quasiexperimental Evidence from an Indian State. Global Journal of Finance Management, 1: 171-183.

[37] Parveen, S. 2008. Access of Rural Women to Productive Resources in Bangladesh: A Pillar for Promoting their Empowerment. International Journal of Rural Studies, 15(1): 1-8.

[38] Parvin, G. A., Ahsan, S. M. R., and Chowdhury, M. R. 2005. Women Empowerment Performance of Income Generating Activities Supported by Rural Women Employment Creation Project (RWECP): A Case Study in Dumuria Thana, Bangladesh. The Journal of Geo-Environment, 4:47-62.

[39] Rahman, M. 2003. Growth of Poultry Industry in Bangladesh Poverty Alleviation and Employment Opportunity. In: Proceedings of 3rd International Poultry Show and Seminar, Organized by World's Poultry Science AssociationBangladesh Branch. 1-7.

[40] Rahman, M. H. and Naoroze, K. 2007. Women Empowerment through Participation in Aquaculture: Experience of a Largescale Technology Demonstration Project in Bangladesh Journal of Social Science, 3(4): 164-171.

[41] Reardon, T., Berdegué, J. and Escobar, G .2001. Rural Nonfarm Employment and Incomes in Latin America: Overview and Policy Implications. World Development, 29(3):411-425.

[42] Salawat, N., Hasan, S. S., Khan, A. S., Rahman, M. S., Hoque, M. M. and Moonmoon, M. 2013. Study on Knowledge and Attitude of Mushroom Growers at Selected Upazilas of Dhaka. Bangladesh Journal of Mushroom. 7 (1): 49-57.

[43] Sarker, A. S. and Rahman, M. H. 2007. The emerging perspective of governance and poverty alleviation: A case of Bangladesh. Public Organization Review, 7: 93-112. Available at: http//DOI 10.1007/s11115-006-0023-y. 
[44] Shamsuddoha, M. 2009. Development of Livestock Sector through Leading NGO in Bangladesh. The Annals of the "Ştefan cel Mare" University Suceava. Fascicle of the Faculty of Economics and Public Administration, 9(1): 1-9.

[45] Sheheli, S. 2012. Improving livelihood of rural women through income generating activities in Bangladesh. $\mathrm{PhD}$ Thesis/Dissertation, Division of Agricultural Economics, Hambolt University Berlin, Germany.

[46] Siddique, Z., Batool, S. A. and M. Farooq. 2009. An assessment of female participation in income generating activities in agriculture sector in rural areas of district Sialkot. The Journal of Animal \& Plant Sciences, 19(4):230-233.

[47] Smucker, T. A. and Wisner, B. 2008. Changing Household Responses to drought in Tharaka, Kenya: Vulnerability, Persistence and Challenge. Journal Compilation at Overseas Development Institute. Blackwell Publishing.

[48] Sonaiya, E. B. 2007. Family Poultry, Food Security and the Impact of HPAI. World's Poultry Science Journal, Vol. 63.

[49] Steele, F., Amin, S., and Naved, R. T. 2001. Savings/Credit Group Formation and Change in Contraception. Demography, 38(2): 267-282.
[50] Sultana, B., Zaaba, Z. B. and Umemoto, K. 2010. Women's Empowerment Through the Development of Micro Entrepreneurship in Rural Bangladesh. Social Science, 5: 1-9. DOI: $10.3923 /$ sscience.2010.1.9.

[51] Sultana, S. and Hasan, S. S. 2010. Impact of Micro-Credit on Economic Empowerment of Rural Women. The Agriculturists, 8(2): 43-49. Available at: http//banglajol.info/index.php/AGRIC/article/view/7576.

[52] UNIFEM 1998. Gender Considerations in Sectoral Planning for Pacific Island Planners in Agriculture, Fisheries and Forestry, UNIFEM Pacific Regional Office, Suva, December.

[53] Yaqoob, M., Menhas, R., Akhtar, S., Mushta, A. and Mehmood, F. 2014. Economic Role of Women: A Systematic Analysis of Women Income Generating Activities in Rural Areas of Pakistan. World Applied Sciences Journal 31 (4): 488-490. DOI: 10.5829/idosi.wasj.2014.31.04.346.

[54] Zaman, H. 2009. Assessing the Poverty and vulnerability Impact of Micro-Credit in Bangladesh: A Case study of BRAC Washington, D. C.: The World Bank. 